\title{
Democracy's Deficit: The Role of Institutional Contact in Shaping non-White Political Behavior
}

\author{
Marcela García-Castañon \\ San Francisco State University
}

Kiku Huckle

Pace University

Hannah L. Walker

Rutgers University

Chinbo Chong

University of Michigan

\begin{abstract}
This paper examines the effect of institutional contact on political participation among non-White communities. While both formal and informal institutions help shape community citizen participation, their effects vary on the historical inclusion (or exclusion) of certain racial groups. Formal institutions, like political parties, have historically excluded or neglected non-White and immigrant voters. We argue that for the excluded or neglected, nontraditional political institutions, like community based organizations, serve as supplements to facilitate political incorporation and engagement. These informal institutions help develop skills and resources among their constituents, and offer routine opportunities to participate. We use the 2008 Collaborative Multi-racial Post-Election Survey (CMPS) to test the differential effects of self-reported voter mobilization through nonpartisan and partisan institutional contact to explain variations among racial groups by the intensity of contact, occurrence of co-ethnic outreach, and type of institutional mobilization. We find that while contact by a partisan/political institution, like a political party
\end{abstract}

Address correspondence and reprint requests to: Marcela García-Castañon, San Francisco State University, 1600 Holloway Avenue, HUM 304, San Francisco, CA 94132. E-mail: mgcs@sfsu.edu 
or campaign, has an overall positive effect on political participation for all voters, contact by a nonpartisan/civic or community group is substantively more important for Latino and Asian American voter mobilization. Our analysis therefore offers cohesive evidence of how voters interact with and are affected by mobilization efforts that attends to differences across racial and ethnic boundaries, and variations in institutional contact.

Keywords: political behavior, non-whites, engagement, CBOs, political parties, formal and informal institutions.

The 2016 United States Presidential election was one of the most diverse to date: almost one in three eligible voters was non-White (Krogstad et al. 2016), although the future implications of this ongoing demographic change are tempered by non-White voters' consistently low turnout rates. Mobilization is one of the most effective ways to significantly boost non-White participation rates, thereby increasing the potential for non-Whites to engage in political activities, and specifically to alter electoral outcomes (Rosenstone and Hansen 1993). Yet traditional political institutions, such as campaigns and political parties, tend to focus their limited resources on mobilizing likely voters, and to almost exclusively electoral activities (voting, registering, etc.). Non-Whites often are less well resourced, have intermittent voter turnout rates, and a high proportion of new voters, and so are often ignored by partisan institutions leveraging limited resources. Further, the increasingly abrasive political environment increases party incentive to promote nativist tendencies in lieu of courting new and minority voters as a way of attempting to "balance their current constituencies against possible future ones" (Erie 1988; Hochschild 2009).

While disparities are acknowledged, the mobilization literature lacks a cohesive framework for accounting for differences in partisan contact between Whites and non-Whites. Further, few studies examine the simultaneous role of civic and community institutions' efforts to mobilize non-White communities. Instead most studies emphasize or address the mobilization of only one racial group (Michelson 2003a; 2003b; Ramirez 2013), while studies that are not race specific are completed among mostly White participants and emphasize voting behavior (Campbell et al. 1960; Rosenstone and Hansen 1993; Verba, Schlozman, and Brady 1995). ${ }^{1}$ This paper endeavors to develop a framework that distinguishes between informal (nonpartisan) civic or community institutions and formal (partisan) political institutions, and acknowledges the distinct effect of contact on political participation beyond voting across racial groups. ${ }^{2}$ 
Our analysis is premised on the racial disparity in traditional political organizations' mobilization efforts that target primarily White voters who tend to participate at higher rates than racial minorities (File 2013). We ask and offer a counterfactual: if racial minorities were contacted more, and contacted by organizations or people that look like them or are from their community, would they participate in political activities at rates comparable to Whites? To that end, we argue that three aspects of contact-intensity of contact, co-ethnic contact ${ }^{3}$, and type of organizational contact-matter for non-White political participation in ways that differ from Whites. While intensity of contact should increase the participation of all racial groups, more intense outreach promises to have a larger positive impact on groups historically excluded in American politics. Co-ethnic contact should increase the participation of non-Whites, whose inclusion in traditional politics is contested resulting in distrust of the political system, as it taps into community connection rather than trust in the political system. Thus, outreach by someone of their own group may bridge the trust gap and result in positive effects on participation across a variety of political activities. Lastly, outreach efforts by civic or community institutions promise to have a larger impact on the participation of Asian Americans and Latinos ${ }^{4}$ than those by political institutions. This is because a large component of both groups is either immigrant or immigrant-derived, and therefore needing additional outreach and education in order to be effectively brought in as participants in the American polity.

We draw on the Collaborative Multi-racial Post-Election Survey (CMPS) to evaluate the relationship between types of outreach efforts and participation outcomes (Barreto et al. 2008). Because mobilization efforts by a range of organizations foster participation both in and out of the voting booth, we include non-voting activities in an analysis of participation outcomes alongside voting (Han 2016). We use descriptive statistics to illustrate racial distinctions in mobilization and participation, and then ordinary least squares (OLS) regression to predict the mobilizing power of increased community based contact on non-White political participation.

It is important to note that although we develop a causal account of the relationship between institutional contacts and political engagement, we employ a cross-sectional survey to test the implications derived from our framework. The analysis presented in this paper is therefore correlational in nature. However, we offer a comprehensive theory for understanding the relationship between mobilization and participation that places Whites in a comparative framework with Blacks, Latinos, and Asian Americans, 
and posit that culturally competent efforts targeted to the needs of non-White groups promise to bring them into the polity. We build on research identifying the under-mobilization of new voting groups as democratically problematic, and the theory and evidence suggest that efforts to incorporate these groups will yield participatory dividends. We therefore lay the necessary groundwork for, "scholars and pundits [who] pour over election results and lament 'underperformance' of minorities," to move forward with a focus on the institutional factors that can enhance the equal participation of an increasingly diversifying electorate (Barreto 2018, 187).

\section{RELEVANT LITERATURE}

The conventional wisdom on political participation focuses on socioeconomic status and mobilization as the two mechanisms driving engagement. Education, wealth, and civic skills increase political engagement by facilitating resources like time, knowledge, and energy to participate (Campbell et al. 1960; Rosenstone and Hansen 1993; Verba, Schlozman, and Brady 1995; Wolfinger and Rosenstone 1980). Being asked to participate is equally important and can help overcome socioeconomic deficits, and the importance of resources and mobilization to participation extends to a wide variety of political practices beyond voting, like signing a petition, attending protests, donating to campaigns, and so forth (Rosenstone and Hansen 1993; Verba, Schlozman, and Brady 1995). Researchers identifying the importance of mobilization have focused on efforts by political institutions, especially parties and campaigns (Caldeira, and Patterson 1990; Wielhouwer and Lockerbie 1994). Parties and campaigns have routine, electoral incentive to mobilize voters, but this incentive also leads to institutional neglect of sub-groups of voters deemed unlikely to participate: the poor, the young, and people of color (Rosenstone and Hansen 1993). This paper focuses on the role of civic organizational contact of non-Whites as an avenue for overcoming neglect by political parties and campaigns despite the increased electoral presence of these groups.

\section{The Electoral Incentive to Overlook People of Color}

The demographic shifts of the American electorate are clear: a majorityminority U.S. population is on the horizon due to the dramatic and 
ongoing growth in Latino and Asian American populations (Frey 2018). According to a recent Pew Hispanic Report, there was an estimated 27.3 million eligible Latino voters for the 2016 presidential election, representing a 40\% increase since 2008 (Krogstad et al. 2016). Asian Americans made up approximately 5\% of the U.S. population as of 2008 (Wong et al. 2011) and are currently the fastest growing racial group ("The Rise of Asian Americans" 2013). Yet, Latino and Asian American voters are consistently overlooked by partisan mobilization efforts (Leighley and Vedlitz 1999; Lien, Conway, and Wong 2004; Lien et al. 2001; Uhlaner, Cain, and Kiewiet 1989; Wong 2000; 2006). This is because electoral calculations by political parties and campaigns create disincentives for non-White mobilization, historically premised on their relatively small size, or expectations of electoral capture (Frymer 2008). ${ }^{5}$

Black Americans have achieved the most institutional inclusion, but risk electoral capture backlash. Latinos are verging upon electoral capture, a condition exacerbated by the fact that their votes are not yet considered essential to national electoral success. Asian Americans, the smallest of the three groups, have been historically the most split between parties, but in recent years anti-immigrant rhetoric may be pushing them firmly into the Democratic Party (Peters 2016). ${ }^{6}$ All three groups are therefore threatened by electoral capture, and their relative size makes them a low value target for institutional outreach.

As a result, non-Whites often compete for minimal attention from political institutions which, at best, results in the neglect of non-White groups. Yet at its worst, a preference for White voter mobilization historically resulted in a partisan incentive to actively vilify non-Whites (Barreto and Nuño 2011; Gay 2002; Michelson 2003a; Pantoja and Segura 2003a; 2003b). These overtures can be both overtly and implicitly racist (Bonilla-Silva 2014; Jacobson 2008; Schildkraut 2005; Wilson 2001). Such denigration erodes trust for partisan institutions among new voting and low-turnout populations, pushing them further to the political margins (Barreto and Nuño 2011; Gay 2002; Michelson 2003a; Pantoja and Segura 2003a; 2003b). Neglect, moreover, reinforces already low levels of political efficacy documented by scholars elsewhere, leading non-Whites to increasingly subscribe to the belief that elected officials do not care about or respond to the needs of people like them (Barreto 2018; Nuño 2007).

More importantly, the presumption that non-Whites will continue to fail to participate is unfounded. Research has found that the act of registration, regardless of whether that act happens as a result of age, education, 
or naturalization, "appears to mark a decisive cut-point in the level of political interest" which then causes "low resource voters [to] act more like high resource voters" (Cho et al. 2006, 158). Further, voting itself predicts the likelihood of voting in the future, and voter mobilization and turnout is likewise associated with participation in other types of activities beyond voting (Finkel 1985; Green and Shachar 2000; Stockemer 2014). As such, political mobilization works to incorporate citizens into the polity, both inside and outside the voting booth (Barreto 2018; Ramirez et al. 2018). Neglect in mobilizing communities of color to the ballot box thus contributes to a self-reinforcing cycle of neglect, which in turn results not only in low voter turnout, but also in decreased civic engagement and diminished political incorporation overall. Put simply, Ramirez et al. write, "the stakes go beyond a single election outcome; the story here is about the political incorporation (or the continued lack thereof) of some groups over others, to the detriment and erosion of American democracy" (2018, 158).

Within this context, then, we push to expand the mobilization literature beyond the effect of partisan contact, which is traditionally focused on White political engagement. Further, the tradition of neglect and vilification by traditional partisan institutions produces a distrust of those same institutions for non-White voters, making nonpartisan mobilization efforts more successful. This supposition is supported by research into Black participation, as well as other marginalized populations that have had to look to informal political institutions to gain entry to formal politics.

\section{Incorporation in the Face of Partisan Neglect}

Community based organizations facilitated the participation of the Black community by providing institutional linkages necessary for participation in the face of partisan institutional neglect. These alternative mobilization avenues emerged to increase pressure on political institutions to be more inclusive of Blacks, build civic and political capital through nongovernmental institutions, and center the Black church and schools as important sites of political socialization (Barker and McCorry 1976; Dawson 1994; Nelson and Meranto 1977; Walton 1994; Walton and Orr 2005). Further, these organizations helped develop a politicized racial identity, and increase political efficacy (Dawson 1994; Shingles 1981; Walton 1994). More recently, however, the importance of the 
Black church and racial identity to predicting Black behavior and attitudes has declined, while mobilization efforts by institutions like the Democratic Party have, in turn, become key motivators for their turnout (Philpot, Shaw and McGowen 2009). In other words, the power or necessity of community based organizations (CBOs) to Black participation has diminished as their inclusion in traditional partisan institutions has increased. This indicates a trajectory of Black political incorporation that began with community based organizations producing a higher turnout rate in the face of partisan neglect, and resulted in a marginal degree of representation for Blacks who now earn sustained attention from parties and campaigns. It is important to note that much of this success was rooted in mobilizing Black citizens to participate broadly, both in and out of the voting booth.

Examples of the mobilizing capacity of nonpartisan community based organizations are not limited to Black Americans. Schools were a primary site of Chicano youth mobilization in the late 1960s and early 1970s (Haney-Lopez 2003). Anti-poverty organizations were instrumental to organizing the poor during the same time period, leading to important wins in the area of public housing and welfare rights (Ernst 2010; Juravich 2017; Reese and Newcombe 2003). More recently, labor unions have played an important role in mobilizing immigrants, even though they are barred from voting as non-citizens (Terriquez 2011; Varsanyi 2005). In short, nonpartisan organizations have consistently provided marginalized populations outside the mainstream of politics with alternative means of engaging in American politics and with elected representatives, historically and now.

Community based organizations likewise are often culturally competent in their tactics to mobilize marginalized populations, increasing the likelihood that they will do so successfully (Stevens and Bishin 2011). This in part explains the success of co-ethnic contact, which serves as a signal that their interests may be better represented than before any representation had been achieved (Pantoja and Segura 2003a; 2003b). These views are supported by Zepeda-Millán's account of the power of informal organizing through activities like soccer leagues, which increased widespread participation in the 2006 immigrant's rights marches (2017). In other words, co-ethnicity, either via organizer, leader, or through ethnic centered organizations, engenders greater trust than do mainstream political actors and institutions (Barreto and Nuño 2011; de la Garza, Abrajano, and Cortina 2008; Junn and Masuoka 2013; Michelson 2003b; Ramakrishnan 2005; Wong 2006; Wong et al. 2011). This trust functions 
to improve the belief in the importance of participating and in the value of collective action. Likewise, Ramirez et al. (2018) find that nonpartisan institutions are more likely to target immigrants and Spanish speaking Latinos, further expanding the reach of these nonpartisan organizations and also demonstrating their willingness to include all members of the Latino community. While the literature has focused on Latino participation, it suggests that nonpartisan organizations can also bring a level of cultural competency to the mobilization of other communities of color, which can explain the success of their mobilization efforts.

\section{How Community Based Organizations Facilitate Participation}

At first glance, it may appear that CBO strategies of engagement do not differ significantly from those of traditional partisan organizations, such as parties and campaigns (Leighley 2001). We argue that, beyond differences in the populations they target, CBOs significantly differ in their approach to voter incorporation. While parties work to mobilize individuals already possessing of the time, interest, and resources for a particular event, CBOs emphasize organization in addition to mobilization. This includes not only asking people to participate, but also showing them how, giving them support, and cultivating a sense of importance around their actions (Christens and Speer 2011; Klofstad and Bishin 2013; LeRoux and Krawczyk 2014; Owens 2014; Terriquez 2011; Varsanyi 2005). For these reasons, the engagement that develops out of CBO contact builds the necessary framework for sustained civic engagement over time in populations that would otherwise be neglected and excluded from partisan mobilization efforts (Christens and Speer 2011).

Such organization benefits both voters and CBOs. Individuals gain access to the political realm, and CBOs gain the support of political actors who are incentivized to participate out of a sense of allegiance to an organization that has helped them. Owens (2014) refers to this as "the strategic exchange of resources," and his work demonstrates that CBOs are central to helping even those least likely to participate (ex-offenders) to overcome participation barriers (Lerman and Weaver 2014). Han identifies this strategic exchange as a double-barreled approach by CBOs especially adept at "getting people to do stuff" (2014, 1), which is particularly significant for marginalized communities that are overlooked by partisan mobilization efforts. 
Finally, not only are CBOs well positioned to fill the civic void left by parties and campaigns, but these organizations also respond to a different set of incentives than do partisan institutions. Political parties and campaigns are incentivized to mobilize as many people as possible to make donations and turnout to vote in order to win elections. Community based organizations, in contrast, are more concerned with forwarding a very narrow agenda. Motivating political actors to electoral participation and the lobbying elected officials is then a means to that goal, rather than an end in itself. Further, many CBOs are interested in building the human capital in the communities they serve for the express purpose of betterment of that community. For some CBOs, such as churches and schools, the task of organizing their membership, building leadership capacity and civic skills necessary to political participation is vital to the persistence of the institution itself.

In short, where other scholars assume that the sorts of strategies engaged by parties and campaigns do not differ in analytically important ways from those engaged by community based organizations (Leighley 2001), following Han (2009; 2014), we assume the opposite. Indeed, organization undertaken by nonpartisan institutions is key to mobilizing participation among marginalized populations. Moreover, minorities and the poor may be targeted by community based organizations for the same reasons they are neglected by formal partisan institutions: because their narrow interests have been historically neglected within the political realm.

\section{THEORY AND HYPOTHESES}

Our argument is premised on the understanding that the American political system defaults to a "likely voter" that is primarily White. This has necessitated alternate forms of political engagement for non-White communities that have not received the same level of attention from political actors and institutions. To that end, we theorize that the type and intensity of outreach efforts engaged in by nonpartisan institutions will have a stronger effect in mobilizing non-White populations. We develop three interlocking hypotheses derived from our theoretical framework regarding the differential impact of institutional contact on political participant among racial subgroups: that the intensity of contact, the ethnicity of the contacting individual or organization, and the type of institution impacts the effectiveness of outreach to non-White political participation. 
First, we address the simplicity of outreach - the most effective way to get individuals involved is to ask them to participate. We therefore argue that all racial groups will be responsive to political mobilization efforts and requests to participate. The testable implication derived from this proposition is that a greater number of requests to participate will be positively related to participation. We refer to this as the intensity of contact hypothesis, and we expect that it will hold across all racial groups. However, non-White communities have historically been neglected by, or actively excluded from, the mobilization efforts of parties and campaigns. As such, the size of the positive impact of intensity of contact on participation outcomes will be larger for non-Whites, who even when controlling their previous voting behavior or competitive status, are less likely than Whites to be contacted overall. This generates the following hypotheses:

HyPothesis 1: More institutional contacts will lead to higher rates of participation for all racial subgroups.

HyPOTHESIS 1A: The size of the effect of number of institutional contacts will be larger for non-Whites than Whites.

We next argue that intra-group mobilization through institutional co-ethnic contact has the potential to increase political participation among minorities. The at-times hostile political environment ${ }^{7}$ against Blacks, Latinos, Asian Americans, and immigrants in combination with the history of neglect makes distrust of political elites a rational response for non-White communities (Barreto and Nuño 2011; Gay 2002; Michelson 2003a). As such, the second testable implication of our theoretical framework is that institutional co-ethnic contact will be positively associated with political participation among non-Whites. Our understanding of co-ethnic contact is largely derived from research on Latinos, but we expect other racial subgroups will have a similar positive response due to their similar experiences of antagonism and ostracism from the established political regime. This leads to the following co-ethnic contact hypothesis:

HyPOTHESIS 2: Institutional contacts from a co-ethnic will lead to higher rates of participation only for non-Whites.

The final theoretical proposition we consider is that mobilization efforts by civic and community institutions will be more important for Asian 
Americans and Latinos, who are currently neglected by mainstream political institutions, than for Blacks. Blacks enjoy some recognition from the Democratic Party as an important voting bloc, and thus are increasingly incorporated into party mobilization efforts (Philpot, Shaw, and McGowen 2009). We theorize that their newly incorporated status decreases the impact of nonpartisan outreach on Black participation levels. In contrast, we hypothesize that Asian Americans and Latinos will demonstrate higher rates of participation following contact by a nonpartisan (and therefore, more trusted) institution as compared with partisan contact. We refer to these as the institutional contact hypotheses:

HyPOTHesis 3: Contact by nompartisan (civic and community) institutions will increase participation among Latinos and Asian Americans.

HyPOTHESIS 3A: Partisan and nonpartisan contact will have the same impact on Black participation rates.

We expect that successful mobilization will be reflected in a wide variety of activities inclusive of but not limited to voting. Community based organizations provide routine opportunities for engagement outside of elections, and mobilization by all kinds of institutions enhance and support the incorporation of citizens into the polity, which should be reflected outside the voting booth (Han 2016; Ramirez et al. 2018; Stockemer 2014). As such, our explicit expectation is that mobilization around elections has positive spillover effects for civic engagement, conceived of broadly.

\section{DATA AND METHODS}

We use the 2008 CMPS dataset with 4,563 valid respondents, all registered voters from the 2008 Presidential election. The benefit of the CMPS, as Wong (2015) and others note, is its robust sampling of Black Americans, Asian Americans, and Latinos, in addition to Whites. ${ }^{8}$ This makes it possible to compare patterns of self-reported behavior across all racial groups. ${ }^{9}$ Further, the CMPS was available in English, Spanish, Mandarin, Cantonese, Korean, and Vietnamese, and respondents could choose their language of interview, facilitating both the response rate and ability of respondents who are not native English speakers to participate. This is particularly important when examining racial groups with large immigrant populations, such as Latinos and Asian Americans. 
Moreover, the CMPS is unique in the measures important to our analysis. The survey included several questions measuring whether one had been mobilized to participate as well as participation outcomes. To our knowledge, no other survey both includes the requisite measures to the questions under study and boasts a robust sample of the racial subgroups in question. ${ }^{10}$ The 2008 CMPS therefore offers an important opportunity to assess the viability of our theory, and our analysis lays the necessary foundation for future experimental work on the topic at hand.

Our primary outcome variable is a nine (9) item political participation index. We chose to create this variable both to account for the various ways different racial groups participate as well as to effectively measure respondents' degree of self-reported engagement. Five of the nine items measure traditional or formal modes of participation: whether the respondent voted in the 2008 general election, attended a political meeting or speech in support of a particular candidate or party, worked for a candidate or party, donated money to a candidate or party, or wrote a letter or email to an elected official. We additionally included four acts that are not campaign-specific but are still political: whether the respondent in the past year took part in a protest or demonstration, tried to convince family or friend to vote, read or posted a comment about politics on a blog or website, or used a social networking page or listserv to talk about politics.

We include a wide variety of political acts in our measure of participation for a number of reasons. Groups that are historically politically marginalized are more likely to participate informally, since such activities offer a lower barrier to entry; successful mobilization is likely to manifest in a broad spectrum of activities beyond voting; and the measure of voter turnout in the CMPS is self-reported and therefore threatened by social desirability bias, which research demonstrates does not likewise bias selfreports of other types of activities (Holbrook and Krosnick 2010a; 2010b; Persson and Solevid 2013; Zukin et al. 2006). A robust analysis of the impact of mobilization efforts on political engagement should therefore include participatory measures inclusive of but not limited to voting.

We begin with the premise that racial groups have a different experience of and relationship to the political system. As such, we model each group separately. This allows us to identify which of our explanatory and control variables affect each group's rate of political participation. We then calculate the fixed effects of the variables of interest on participation outcomes, as well as the predicted levels of participation for each group from our race- 
specific OLS regression models. ${ }^{11}$ We have three primary explanatory variables to test our hypotheses about racial minority political mobilization: intensity of contact, co-ethnic contact, and type of institutional contact. All three measures are developed from the CMPS questions asking whether respondents were asked to register or to vote, by whom (person or organization), the party of the contacting agent, and their ethnicity. ${ }^{12}$

Given the disparity in political outreach between racial groups, we hypothesize that more frequent contact encouraging participation (or a greater intensity of contact) will have a stronger influence on Latino, Asian American, and Black voters as compared with Whites. To measure intensity, we count the number of different people or organizations that contacted the respondent. ${ }^{13}$ Possible responses include a candidate running for office or their campaign, political party representative, an independent group not directly tied to the candidates, or a nonpartisan organization working in your community. Respondents could answer affirmatively to each response, making a total of four "types" of contact possible. This variable ranges from 0 (no contact) to 2 (for 2 or more types of contact). ${ }^{14}$

We are also interested in the effect of the type of organizational contact on political participation rates. We hypothesize that contact by a nonpartisan civic or community institution will have a larger influence on Asian American and Latino participation than contact by a party or campaign due to an historical distrust of traditional partisan institutions. In contrast, we expect that there will be no difference between partisan and nonpartisan group contact on both Black and White participation rates given established pattern of outreach to both racial groups by both types of organizations. We created two variables from the same question used to measure intensity: "Who contacted you?" The variable "partisan contact" indicates a candidate running for office or a political party representative, and "nonpartisan contact" represents outreach by community or other nonpartisan organizations.

While the literature regarding co-ethnic mobilization mostly focuses on Latinos, we developed a "co-ethnic contact" hypothesis to test whether the effect of co-ethnic mobilization applies to all racial groups. Respondents who reported having been asked to register or to vote were also asked about the race of the person who contacted them. We created dichotomous variables for each of the racial categories (Latino, Asian American, Black, and White) to be applied in the relevant regression models, with the " 0 " term referring to contact from a person or organization of any race other than that of the respondent. 
A significant portion of the literature addresses the differing impact of outreach and other traditional demographic features on immigrant political participation. To account for this, we created a dichotomous variable "Born in US" to delineate between immigrant and later generations. This variable is only used in regressions for Latino and Asian American respondents since upward of $95 \%$ of White and Black respondents are born in the USA.

All other socioeconomic control variables are included in our regressions: party, home ownership, income, ${ }^{15}$ education, gender, and age. We also account for religion as a major component of community and cultural identity, along with the direct link between church and political mobilization particularly within the Black community. Recent work demonstrates that religion may continue to influence racial identity and political attitudes among racial subgroups (Wong 2015), and high church attendance has been shown to correlate with high levels of political engagement, providing ample justification for inclusion of this variable (McDaniels 2008; Putnam 2010; Wong 2015). To that end we include a variable for church attendance; this is a six-point scale ranging from "never" (value $=1$ ) up to "more than once a week" (value =6). We also created a dichotomous "co-ethnic church" variable to account for the community aspect of religion, which may be amplified if one attends with a predominantly co-ethnic congregation.

Lastly, we include a dichotomous variable measuring whether respondents report having personally experienced discrimination or been treated unfairly on account of their race. A growing body of research demonstrates that perceived racial discrimination and resulting feelings of group threat are linked to increased political participation (Bowler, Nicholson, and Segura 2006; Pantoja, Ramirez, and Segura 2001; Pantoja and Segura 2003a; 2003b; Pedraza 2014). Further, we premise our framework on the idea of institutional neglect, and discrimination may point to a way of identifying perceptions of neglect more broadly. Thus, perceptions of discrimination, which may increase political engagement, may also alter perceptions of institutional neglect and result in further increased participation. For the same reasons, we also include a dichotomous measure of racial linked fate.

\section{Findings}

Our paper is premised on the idea that White voters are consistently asked to participate at higher rates than other racial and ethnic groups, a fact that 
is reflected in the CMPS data (see Table 1). White respondents reported an average of .44 contacts as compared with Blacks (.41), Latinos (.31), and Asian Americans (.28). A $\chi^{2}$ test found that these differences are statistically significant. ${ }^{16}$ There is one anomaly to the pattern of Whites being contacted most often: Black respondents reported being "mobilized" asked to participate, vote, or engage-more frequently by nonpartisan institutions than did White respondents (13.3 and $11.6 \%$, respectively). We conducted logistic regression to predict the effect of race on the likelihood of being contacted at all, and then contacted by partisan and nonpartisan institutions.

We found that being Black produced no significant difference in likelihood of mobilization as compared with Whites. However, Latinos and Asian Americans are predicted to be contacted 6.4 and $6.7 \%$ less than Whites, respectively. Both findings are significant to the $p<.01$ level. The findings are similar for predicting partisan contact $(3.0$ and $6.0 \%$ less) and nonpartisan contact (4.2 and 3.8\% less) for Latinos and Asian Americans as compared with Whites. The likelihood of Black mobilization by either partisan or nonpartisan institutions was not statistically different from that of White voters. Given the connection between mobilization and participation, it is unsurprising that Whites also report the highest levels of participation: White respondents have the highest mean score on the participation index (3.1) and are closely followed by Blacks (3.0, see Table 1).

We argue that communities of color would participate at higher rates if they were also mobilized at greater levels. Given the historical context of institutional neglect, we test whether greater intensity of contact (as measured by having been asked by multiple sources to register), mobilization via nonpartisan civic and community institutions, and co-ethnic mobilization will have a positive effect on non-White political participation.

Our first hypothesis rests on the theory that the simplest way to increase participation is by asking (Rosenstone and Hansen 1993; Verba, Schlozman, and Brady 1995). We predict that a larger number of "asks" to participate will produce a higher rate of participation for all racial groups (Hypothesis 1). In the observed data, Whites participate at the highest rate of any group (3.1), followed by Blacks (3.0), Latinos (2.6), and Asian Americans (2.4), regardless of mobilization efforts. In our regression models, increased contact produces positive and significant coefficients for all racial groups, supporting our first hypothesis, and providing continued support for past research into the significance of mobilization efforts to all racial groups' political participation. 
Table 1. Levels of institutional contact and political participation, among racial subgroups in the CMPS

\begin{tabular}{lcccc}
\hline Who asked to register: & Latino $(\boldsymbol{\%})$ & Asian American $(\boldsymbol{\%})$ & Black $(\boldsymbol{\%})$ & White $(\boldsymbol{\%})$ \\
\hline Not asked & 74.5 & 76.56 & 69.1 & 67.5 \\
Partisan contact & 17.7 & 16.5 & 17.1 & 20.92 \\
Nonpartisan contact & 7.8 & 6.9 & 13.3 & 11.6 \\
Avg. no. contact & .31 & .28 & .41 & .44 \\
Asked once & 22.5 & 21.6 & 25.3 & 25.9 \\
Asked twice & 3.0 & 1.8 & 5.6 & 6.6 \\
Participation index & & & & \\
0 Acts & 4.3 & 3.6 & 1.5 & 1.1 \\
1 Act & 24.6 & 23.4 & 17.0 & 16.2 \\
2 Acts & 33.1 & 37.1 & 32.2 & 28.5 \\
3 Acts & 15.4 & 17.4 & 18.4 & 20.8 \\
4 Acts & 9.3 & 8.7 & 11.2 & 13.5 \\
5 Acts & 6.8 & 6.0 & 9.2 & 9.5 \\
6 Acts & 3.2 & 1.6 & 5.0 & 5.5 \\
7 Acts & 1.8 & 1.7 & 3.0 & 3.5 \\
8 Acts & 1.0 & .4 & 2.0 & 1.0 \\
9 Acts & .4 & .3 & .5 & .4 \\
Mean no. acts & 2.5 & 2.4 & 3.0 & 3.1 \\
\hline
\end{tabular}

However, we further argued that the size of the impact would be larger for non-Whites than for Whites (Hypothesis la), and again find support for this claim. While frequent contact increases White respondents' average participation score by $.15(p<.05)$, it increases participation for Latinos by .22, Asian Americans by .48, and Blacks by .41. Differences for all non-White predictions are statistically significant at the .01 level. Importantly, these effects produce higher predicted rates of participation for both Asian American and Black voters as compared with Whites. While Latinos also experience positive effects from outreach, they are predicted to continue to have a lower level of participation than the other three racial groups (see Figure 1).

Hypothesis 2 predicts that being asked to participate by a co-ethnic will positively impact participation for Blacks, Latinos, and Asian Americans. Although it is primarily Latino politics literature that demonstrates the impact of co-ethnic mobilization, we theorized that the underlying logic behind co-ethnic mobilization would extend to Blacks and Asian Americans as well, given patterns of distrust established by the White-dominated traditional political structure. However, our findings do not support this theory (Table 2). Instead, we find that the mobilizing 


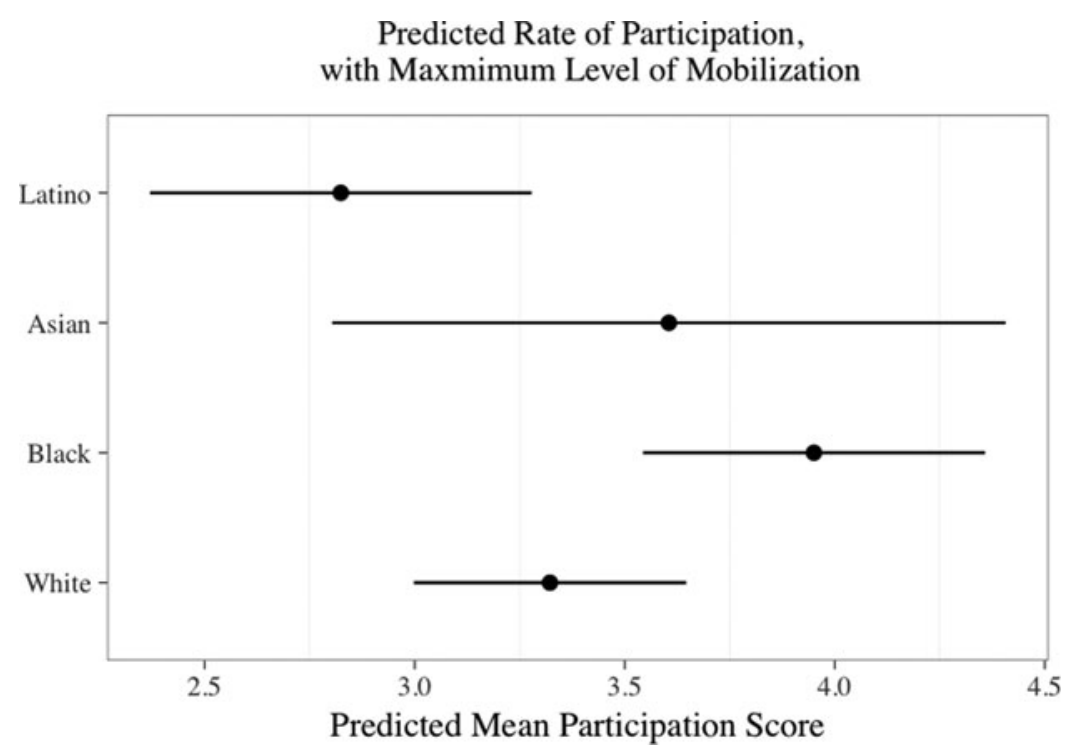

FIgURE 1. The predicted mean score on our participation index with mobilization from two or more types of organizations. Lines represent confidence bands at $p<.05$.

effects of co-ethnic contact holds only among Latinos. This supports existing research, but also identifies the limitation in generalizing specific theories of ethnic political mobilization to other racial groups. In other words: not all non-White groups respond or participate in the same way to co-ethnic appeals. This may be due to the lack of national and ethnic cohesion amongst Asian American respondents. While most Latinos at least share a common language, Asians do not, making a generalized pan-ethnic "Asian American" appeal less effective. Co-ethnic appeals may be less successful for Blacks who, as discussed above, are already somewhat accepted and courted by traditional partisan institutions.

This leads to our third hypothesis, which addresses a key facet of on-going institutional neglect: the difference between outreach by partisan versus nonpartisan institutions on political participation. We argue that being contacted by a nonpartisan civic or community institution will have a positive impact on the participation of non-Whites, but with two qualifications. We theorize that the size of the impact will be greater than that of being contacted by a partisan institution among Asian Americans and Latinos (Hypothesis 3), while nonpartisan and partisan contacts will yield the same or similar results in participation rates for 
Table 2. The impact of intensity of contact and co-ethnic ask on political participation, among racial subgroups in the CMPS

\begin{tabular}{|c|c|c|c|c|}
\hline & Latino & Asian American & Black & White \\
\hline \multirow[t]{2}{*}{ Number of contacts } & 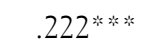 & .479 米等前 & 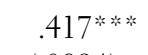 & .148 米 \\
\hline & $(.0714)$ & $(.125)$ & $(.0894)$ & $(.0749)$ \\
\hline \multirow[t]{2}{*}{ Co-ethnic asked to participate } & $.239 *$ & .196 & -.256 & .236 \\
\hline & $(.142)$ & $(.274)$ & $(.192)$ & $(.160)$ \\
\hline \multirow[t]{2}{*}{ Co-ethnic church } & -.0978 & $-.339 \%$ & 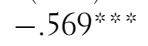 & -.184 \\
\hline & $(.0888)$ & $(.134)$ & $(.126)$ & $(.112)$ \\
\hline \multirow[t]{2}{*}{ US born } & $.154 *$ & $.263^{*}$ & NA & NA \\
\hline & $(.0884)$ & $(.151)$ & & \\
\hline \multirow[t]{2}{*}{ Democrat } & 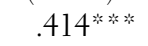 & 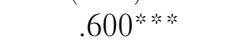 & .832 米净 & 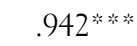 \\
\hline & $(.146)$ & $(.201)$ & $(.245)$ & $(.203)$ \\
\hline \multirow[t]{2}{*}{ Republican } & $368^{* *}$ & $.493^{\text {皮汸 }}$ & .192 & 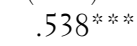 \\
\hline & $(.160)$ & $(.217)$ & $(.327)$ & $(.202)$ \\
\hline \multirow[t]{2}{*}{ Home owner } & .0158 & .154 & .0581 & .145 \\
\hline & $(.103)$ & $(.164)$ & $(.141)$ & $(.172)$ \\
\hline \multirow[t]{2}{*}{ Income (missing) } & .0991 & -.0265 & .0660 & .372 \\
\hline & $(.134)$ & $(.250)$ & $(.202)$ & $(.286)$ \\
\hline \multirow[t]{2}{*}{ Income (20-60k) } & $.313 \%$ & .230 & -.0176 & .176 \\
\hline & $(.132)$ & $(.251)$ & $(.194)$ & $(.288)$ \\
\hline \multirow[t]{2}{*}{ Income (60-100k) } & 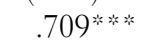 & .340 & $.529 *$ & .456 \\
\hline & $(.160)$ & $(.263)$ & $(.232)$ & $(.298)$ \\
\hline \multirow{2}{*}{ Income $(100 \mathrm{k}+)$} & 1.019 类棌 & .424 & $1.028^{2}$ & $.515 \%$ \\
\hline & $(.188)$ & $(.276)$ & $(.263)$ & $(.311)$ \\
\hline \multirow[t]{2}{*}{ Female } & 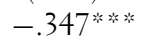 & -.0345 & -.0975 & .0586 \\
\hline & $(.0824)$ & $(.128)$ & $(.124)$ & $(.106)$ \\
\hline \multirow[t]{2}{*}{ Education } & 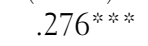 & .0871 & 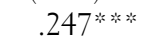 & 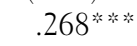 \\
\hline & $(.0315)$ & $(.0560)$ & $(.0578)$ & $(.0499)$ \\
\hline \multirow[t]{2}{*}{ Age: $18-35$} & .0496 & 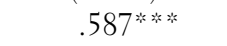 & .117 & .101 \\
\hline & $(.118)$ & $(.190)$ & $(.155)$ & $(.189)$ \\
\hline \multirow[t]{2}{*}{ Age: $65+$} & $.276^{* * *}$ & -.0398 & -.0302 & -.0198 \\
\hline & $(.108)$ & $(.165)$ & $(.158)$ & $(.123)$ \\
\hline \multirow[t]{2}{*}{ Church attendance } & .0376 & -.00348 & .0583 & -.00143 \\
\hline & $(.0265)$ & $(.0418)$ & $(.0400)$ & $(.0330)$ \\
\hline \multirow[t]{2}{*}{ Linked fate } & -.0464 & .0673 & $.0867^{*}$ & -.0250 \\
\hline & $(.0319)$ & $(.0491)$ & $(.0486)$ & $(.0395)$ \\
\hline \multirow[t]{2}{*}{ Discrimination } & .309 皮净 & .133 & $.303^{* * * 2}$ & .191 \\
\hline & $(.0839)$ & $(.126)$ & $(.133)$ & $(.123)$ \\
\hline$N$ & 1377 & 537 & 808 & 988 \\
\hline Adj. $R^{2}$ & .210 & .123 & .148 & .082 \\
\hline
\end{tabular}

Standard errors in parentheses; ${ }^{*} p<.10,{ }^{* * *} p<.05, * * * p<.01$. 
Black respondents (Hypothesis 3a). To test this, we estimated the effect of being contacted by a partisan versus a nonpartisan institution on each racial groups' predicted rates of participation. Those who were never contacted serve as the comparison group. We omitted the variable "total number of contacts" from our regressions to avoid collinearity bias, since the variables are based on the same underlying questions asked by the survey (see Table 3).

We find that nonpartisan institutional contact positively and significantly affects Latino, Asian American, and Black participation rates, but not that of Whites. As predicted, among Asian Americans and Latinos the size of the impact of nonpartisan institutional contact is larger than is the size of the impact of partisan institutional contact, in support of Hypothesis 3. Figure 2 displays the marginal effects by the type of contact among racial subgroups. The difference is particularly marked for Asian Americans, who are most neglected by partisan institutions. Being contacted by a nonpartisan group increases the expected value of participation among Asian Americans by about .75 items on our participation scale. In contrast, nonpartisan contact increases Latino participation by about .45 items. Clearly, where partisan outreach fails, nonpartisan institutions can and do pick up the slack in Asian American and Latino political mobilization.

We further theorized that partisan and nonpartisan contact would have a similar effect on the participation rate of Blacks given their relatively secure (if often ignored) placement within partisan politics and the Democratic Party. The results indicate that being contacted by a political party or campaign has a larger overall effect than does being contacted by a community group. Being asked by a partisan institution increases the expected value of Black participation by about .81 items on the index, compared with an increase of only .4 that comes from being asked by a nonpartisan institution. This supports prior research emphasizing the importance of Democratic Party outreach to Black participation levels, while the impact of churches and racial identity have declined (Philpot, Shaw, and McGowen 2009). Regardless, we were not anticipating finding a weaker effect for nonpartisan outreach, particularly given the strong role that CBOs historically played in Black incorporation and mobilization. Thus, though Blacks have secured a larger slice of partisan institutional attention previously reserved only for Whites, the simultaneous decline in CBO outreach shifts much more responsibilities for mobilization onto partisan institutions. This runs the risk of regressing Black political incorporation given the ongoing nature of electoral capture (Frymer 2011). 
Table 3. The partisan and nompartisan contact on political participation, among racial subgroups in the CMPS

\begin{tabular}{|c|c|c|c|c|}
\hline & Latino & Asian American & Black & White \\
\hline \multirow[t]{2}{*}{ Partisan contact } & $.275^{*}$ & $.380^{* * *}$ & 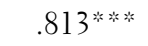 & .188 \\
\hline & $(.113)$ & $(.164)$ & $(.160)$ & $(.134)$ \\
\hline \multirow[t]{2}{*}{ Nonpartisan contact } & $.395^{* *}$ & .747 然的的 & $.439^{* * 2 *}$ & .215 \\
\hline & $(.157)$ & $(.238)$ & $(.186)$ & $(.165)$ \\
\hline \multirow[t]{2}{*}{ Co-ethnic asked to participate } & .199 & .205 & $-.345^{*}$ & .221 \\
\hline & $(.146)$ & $(.275)$ & $(.199)$ & $(.166)$ \\
\hline \multirow[t]{2}{*}{ Co-ethnic church } & -.0942 & 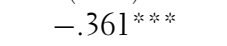 & 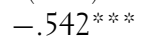 & $-.187^{*}$ \\
\hline & $(.0888)$ & $(.135)$ & $(.126)$ & $(.112)$ \\
\hline \multirow[t]{2}{*}{ US born } & $.153 \%$ & $261^{*}$ & NA & NA \\
\hline & $(.0884)$ & $(.151)$ & & \\
\hline \multirow[t]{2}{*}{ Democrat } & 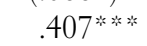 & 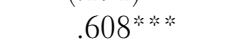 & 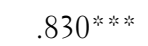 & 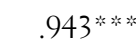 \\
\hline & $(.146)$ & $(.202)$ & $(.244)$ & $(.203)$ \\
\hline \multirow[t]{2}{*}{ Republican } & $367^{* *}$ & $.500^{\text {次况 }}$ & .207 & 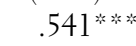 \\
\hline & $(.160)$ & $(.217)$ & $(.326)$ & $(.202)$ \\
\hline \multirow{2}{*}{ Home owner } & .0193 & .140 & .0448 & .147 \\
\hline & $(.103)$ & $(.164)$ & $(.140)$ & $(.173)$ \\
\hline \multirow[t]{2}{*}{ Income (missing) } & .0953 & .0199 & .0755 & .374 \\
\hline & $(.134)$ & $(.253)$ & $(.201)$ & $(.287)$ \\
\hline \multirow[t]{2}{*}{ Income (20-60k) } & $.308^{* *}$ & .293 & -.0130 & .177 \\
\hline & $(.132)$ & $(.254)$ & $(.194)$ & $(.289)$ \\
\hline \multirow[t]{2}{*}{ Income (60-100k) } & 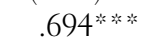 & .382 & $.517^{* \cdots}$ & .459 \\
\hline & $(.161)$ & $(.265)$ & $(.231)$ & $(.299)$ \\
\hline \multirow[t]{2}{*}{ Income $(100 \mathrm{k}+)$} & 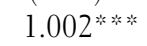 & $.462 *$ & 1.040 然策 & $.515^{*}$ \\
\hline & $(.188)$ & $(.278)$ & $(.262)$ & $(.312)$ \\
\hline \multirow[t]{2}{*}{ Female } & $-.350^{\text {事的婇 }}$ & -.0380 & -.0913 & .0560 \\
\hline & $(.0824)$ & $(.128)$ & $(.124)$ & $(.106)$ \\
\hline \multirow[t]{2}{*}{ Education } & 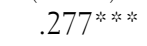 & .0922 & 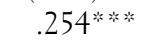 & 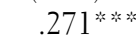 \\
\hline & $(.0315)$ & $(.0561)$ & $(.0575)$ & $(.0499)$ \\
\hline \multirow[t]{2}{*}{ Age: $18-35$} & .0429 & 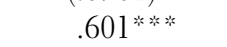 & .0864 & .0928 \\
\hline & $(.118)$ & $(.191)$ & $(.155)$ & $(.189)$ \\
\hline \multirow[t]{2}{*}{ Age: $65+$} & 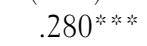 & -.0488 & -.0289 & -.0268 \\
\hline & $(.108)$ & $(.165)$ & $(.157)$ & $(.123)$ \\
\hline \multirow[t]{2}{*}{ Church attendance } & .0368 & -.00749 & .0542 & -.00291 \\
\hline & $(.0265)$ & $(.0419)$ & $(.0399)$ & $(.0330)$ \\
\hline \multirow[t]{2}{*}{ Linked fate } & -.0475 & .0606 & $.0849^{*}$ & -.0233 \\
\hline & $(.0319)$ & $(.0493)$ & $(.0485)$ & $(.0396)$ \\
\hline \multirow[t]{2}{*}{ Discrimination } & 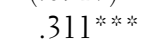 & .130 & $.286^{\text {和 }}$ & .187 \\
\hline & $(.0839)$ & $(.126)$ & $(.132)$ & $(.123)$ \\
\hline$N$ & 1,377 & 537 & 808 & 988 \\
\hline Adj. $R^{2}$ & .211 & .119 & .154 & .081 \\
\hline
\end{tabular}

Standard errors in parentheses; ${ }^{*} p<.10,{ }^{* * *} p<.05,{ }^{* * * *} p<.01$. 


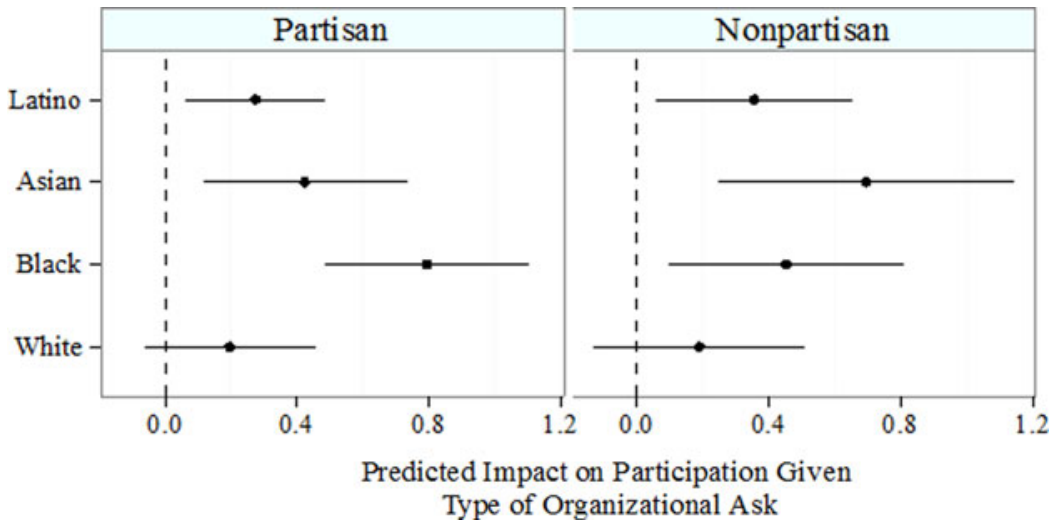

Figure 2. The impact of being asked by a partisan organization to register to vote, compared with the impact of being asked by a nonpartisan organization among racial subgroups. Lines represent confidence bands at $p<.05$.

\section{Formal versus Informal Modes of Participation}

We deliberately created our nine-item index of political participation to include both formal and informal modes of political participation in order to account for the varying patterns of participation exercised by each racial group. We did not want to preference acts, such as voting, over other costlier acts, such as attending a protest. Our scale is therefore indifferent to which kinds of acts respondents take part, and instead assesses their self-reported political engagement overall. However, it is worthwhile to identify if mobilization has a distinct impact on different activities since some participatory acts-such as contacting an elected official-may have larger political implications than others-such as writing on a blog. To complete this analysis, we ran separate regressions for each participation act by race, using the same predictor variables as in the models presented above. ${ }^{17}$

We found little similarity between racial groups and their response to mobilization when examining the individual acts. Asian American response to both partisan and nonpartisan outreach is entirely isolated to traditional acts: attending a political speech, volunteering for a campaign, donating money, and writing letters. ${ }^{18}$

In contrast, partisan outreach produces a positive coefficient for Black respondents in predicting all of our participation measures with the exception of writing letters and voting. Nonpartisan outreach is significant and positive only in predicting Black attendance of political speeches, 
volunteering, and their belonging to a political listserv. This further illustrates our above finding that partisan outreach has a stronger relationship to Black political participation than nonpartisan contact.

Whites, as we already saw, are virtually unaffected by any kind of contact, as they are likely to participate at higher rate overall. Partisan mobilization efforts were only significant in increasing the probability of White voters writing letters to elected officials, while nonpartisan mobilization positively indicate they will vote or follow a listserv.

Institutional contact had the most varied influence on Latino respondents. Partisan contact corresponded with increased Latino likelihood of following a listserv, volunteering, donating money, and writing letters. Nonpartisan contact corresponded to an increased likelihood of encouraging others to vote, attending a speech or rally, volunteering, or writing letters. Co-ethnic contact also had a narrow effect on Latino participation, predicting a significant increase in Latino likelihood of attending a protest or a political speech, only.

The most striking finding of these analyses is that the institutional type of contact-co-ethnic, partisan, or nonpartisan-did not influence outcomes on reported voter turnout, one of the nine activities measured. While we push for greater acknowledgment of the numerous ways individuals make their political preferences known, the fact remains that power comes through voting as a coherent bloc. This is the crux of Black participation literature - that through the continued and ongoing efforts of nonpartisan organizations, Blacks increased voter turnout levels that led to both some level of descriptive representation and increased attention from traditional partisan organizations. Latino and Asian American communities have significantly lower rates of voter turnout, and subsequently lower rates of representation.

This can have a cumulative and negative impact on their ability to garner accountability from elected officials. This is a trend that we theorized could be reversed through community based mobilization efforts, following the historical pattern evident in the Black community, but for which our analysis finds limited support. Nevertheless, we are hesitant to make too much of these findings. Our measure of having voted is self-reported, which research demonstrates is threatened by social desirability bias. Further, this is only one of the many activities we predict through institutional contact, all of which push respondents toward more participatory, if not voting oriented, actions. While a better assessment of the impact of mobilization efforts on voter turnout would draw on validated vote records, this paper focuses on the existing effect of institutional contacts on participation 
more broadly. Social desirability does not likewise threaten self-reports of other types of activities like those examined in the current paper, and we remain confident in the findings presented here.

\section{DISCUSSION AND CONCLUSION}

We set out to determine the effect of increased mobilization efforts, co-ethnic contact, and nonpartisan mobilization on non-White political participation. We ground our hypotheses in the acknowledgment of on-going preferential treatment given to White voters by traditional partisan institutions. Within that context, nonpartisan institutions, including civic and community organizations, provide more representative and responsive outreach for non-Whites groups. While there is speculation that nonpartisan organizations are seen as more trustworthy than partisan organizations, with their history of ignoring and vilifying minority populations, the true power held by nonpartisan organizations rests with the fact that they fill an important civic void left by partisan institutions as it pertains to non-White political mobilization. As a result, we expected that selfreported nonpartisan mobilization would have a greater influence on non-White participation than self-reported outreach by political parties and campaigns.

We first theorized that increased contact overall, and by nonpartisan organizations specifically, would have a larger impact on non-White participation. We found this to be true. While increased outreach also positively affected the rate of White political participation (increasing the predicted participation average by .14) the effect was stronger for Latinos (.21), Asian Americans (.48), and Blacks (.41). Our second hypothesis predicted that co-ethnic mobilization would have a stronger positive effect for non-Whites. While the literature on co-ethnic mobilization has almost exclusively examined Latino respondents, and we also explored its potential influence on Asian Americans and Black voters. We found that co-ethnic mobilization was only effective among Latino respondents. We suspect that the nature of Latino identity and community organizations surrounding the saliency of this particular identity might be driving the strong effect of civic and community institutional outreach (Beltran 2010; Mora 2014). In particular, co-ethnic outreach in Latino communities may be facilitated by more cultural competency than for Asian Americans, or an underlying group consciousness similar to Black linked fate. Nonetheless, our findings support existing theories regarding the importance of co-ethnic contact for 
Latinos, though they do not support an extension of co-ethnic mobilization theory to other racial groups.

Lastly, we argued that nonpartisan organizations would be more effective in mobilizing Latino and Asian American potential voters, whereas partisan organizations would be just as, if not more, effective than nonpartisan organizations in mobilizing Blacks. Our findings supported both sub-hypotheses. Self-reported nonpartisan contact had a greater impact on Latino and Asian American participation levels (.36 and .69, respectively) than self-reported partisan contact (.28 and .42 , respectively). In contrast, partisan contact had a significantly higher impact on Black participation levels (.79) than did nonpartisan contact (.45). Importantly, we found that neither partisan nor nonpartisan contact had any effect on White participation levels, illustrating that persistent organizational outreach is important and consequential for racially differential participation. Put simply, "the problem...is not a political deficiency of people of color, but rather a political deficiency of current campaign outreach efforts" (Barreto 2018, 186-87).

We deliberately constructed a political participation scale that included both traditional forms of participation (e.g. voting), as well as informal modes (such as attending a protest) to avoid excluding less traditional political acts. Yet, we also recognize that it is important to identify which acts are increased through mobilization efforts since some activities - such as donating to a campaign or voting - have more direct political implications. To that end we re-ran each of our models predicting the impact of intensity, co-ethnic contact, and partisan versus nonpartisan contact on each of the individual participation variables that make up our index. We found few consistent patterns across racial groups. We did find that no form of contact or mobilization was associated with increased voter turnout. This finding runs counter to our expectations based in the Black participation literature, where a long history of nonpartisan community mobilizing produced higher rates of voter turnout, representation, and attention from traditional partisan organizations.

It is possible that the success of Black political standing was the result of a long period of mobilization and a deep understanding regarding the necessity of participation due to the experiences with slavery, segregation, and Jim Crow. Perhaps because other communities of color do not have the same motivation for participation, lacking extreme histories of ongoing political oppression. Another possible explanation is the lack of cohesion within Latino and Asian American communities that deal with immigration patterns from a multitude of countries that may or may not share 
language, religion, or other important traditions to tie them together, which would complicate the efforts of nonpartisan mobilization campaigns. It may be that the findings on voting are an artifact of methodology. The measure of voter turnout used here is self-reported. While we are confident in our overall findings, in order to assess the differential impact of mobilization efforts by formal institutions relative to informal, community based ones on voter turnout, scholars should draw on administrative records of vote history. This is an avenue for future research.

We have offered a theoretical framework for understanding the relationship between mobilization efforts undertaken by partisan and nonpartisan institutions and participatory outcomes among Whites, Blacks, Latinos and Asian Americans. We derived testable implications from our theoretical propositions and leveraged the CMPS to evaluate our hypotheses. However, while the findings offered here are supportive of our theory of racialized institutional contact overall, they are correlational in nature. As such, future research should subject our theory to more rigorous causal analysis in the form of field experiments. Such research would greatly add to the work of previous scholars who used experiments to tease out why certain types of mobilizations succeed or fail to activate hard-to-reach and low-propensity voters. One consistent conclusion is that ethnic targeted mobilization efforts (and some specified, from nonpartisan institutions) do elevate turnout of unlikely voters (Abrajano and Panagapolous 2011; Garcia-Bedolla and Michelson 2012; 2014; Ramirez 2005; 2007; Wong 2005). Future work will build on these findings, honing in on the impact of nonpartisan mobilization on voter registration and turnout.

We contribute to the participation literature by parsing out the importance of mobilization for communities of color: while being asked matters, who does the asking - from an institutional perspective - has a differential impact across racial subgroups. We demonstrate that it is not only important to ask, but that the ones asking must also provide a representative or at least responsive dynamic to non-White communities. Such considerations become more salient as an increasingly diverse polity challenges the homogeneity of the American electorate, but only if that diverse electorate participates.

\section{Acknowledgments}

We thank Jaime Dominguez, Luis Fraga, Ricardo Ramirez, and our other anonymous reviewers for the helpful feedback on this version of the paper. We 


\section{also thank the audience from the annual American Political Science Association meeting at Philadelphia, PA 2016. We alone are responsible for the content.}

\section{NOTES}

1. This is not to say that these authors didn't hypothesize about how mobilization would work for non-White communities. Verba, Schlozman, and Brady (1995), for example, discusses the role of the Black church in mobilization efforts. Rather, the focus of these authors was on a "universal" model of participation and mobilization, often one that applied most strongly to White voters, but requires considerable adjustments and variation for non-White voters.

2. While Hispanics are not considered a "racial" classification by the Census, in this paper, we utilize the language of race or racial group to also include the ethnic identification of "Hispanic" or "Latino." Thus, non-Whites refer to Black, Asian American, and Latino voters in this paper.

3. By co-ethnic contact, we mean appeals made by someone of the same race or ethnicity.

4. We qualify the label "Asian American" and "Latino" to include both the foreign and native-born populations throughout the paper, and also account for the respondent's immigrant status in our model.

5. The assumption is that certain groups will overwhelmingly vote for one party, regardless of any outreach efforts: Democrats hold most non-White demographics, though Cubans are overwhelmingly Republican voters, and some Asian American sub-groups have proven more "swing" voters depending on election contexts.

6. This will be true in most contexts, where Asian American voting blocs will be relatively small. In areas where Asian American voting blocs exceed the national average of 4\%, they will be much more desirable targets for political institutions. These regions, however, are very limited: Hawaii, Alaska, and regions of California.

7. Propositions, ballot measures, and hateful rhetoric aimed at Blacks, Asian Americans, Latinos, and immigrants contribute to a "hostile political environment." Politicians who call for mass deportations, deny amnesty or humanitarian pleas; ballot initiatives, laws, and propositions that make life harder for these demographics through the use of shame about a lack of "personal responsibility" or "lawlessness" are just some examples.

8. Respondents' were asked to choose their own racial designation.

9. We rely on self-reported behaviors, and concerns about validity and social desirability effects in reporting engagement are valid. While we cannot validate voter turnout or participation in other activities, it is also true that participation in other activities, such as those examined in our work, are not subject to social desirability bias to the same degree as voter turnout (Holbrook, and Krosnick 2010a; b; Persson and Solevid 2013; Zukin et al. 2006). We therefore view an assessment of participation in eight of the measures of participation as more or less valid and accurate, despite the potential concern of social desirability around the one measure of voter turnout. This thus allows us to still make claims about the connections between institutional neglect and contact and subsequent political behaviors.

10. This includes the 2012 CMPS, which does not include Asian Americans and is not publicly available. The 2016 ANES includes a robust sampling of Blacks and Latinos, but does not include a sizable number of Asian American respondents and does not ask respondents whether or not they were mobilized leading up to the 2016 election.

11. The political participation index is a variable ranging from 0 to 9 , and as such is evaluated using OLS regression. An alternative method of analysis is Poisson regression, since the index is count of number of reported political acts. The findings from a Poisson regression do not substantively differ from those derived from an OLS model.

12. The CMPS does not ask other mobilization questions. However given the established relationship between registration and political participation (Cho et al. 2006), we are confident in the validity of this measure to our analysis.

13. The CMPS does not ask respondents how many unique instances of mobilization they experienced. As such, a candidate or party could have asked the respondent to register multiple times, which would not be picked up by this measure. However we are interested in the effect of mobilization on the participation rates of traditionally ignored constituencies; therefore we anticipate that experiencing outreach from a variety of organizations will yield a positive response on participation rates. 
14. There were few respondents reporting contact from three or four different sources and so we collapsed these categories in order to maintain statistical viability. Alternately, we could use the "mode of communication" question to calculate intensity by counting the number of different ways respondents were contacted (e.g. mail flyer or phone call) rather than the number of types of organizations that contacted them. The "mode of communication" variable also suffers from low cell counts for the higher values, so it does not offer a more nuanced measure of intensity. Further there is a high level of correlation between intensity as measured by organizational contact and intensity as measured by mode of communication (.81), minimizing the likelihood of a differential effect.

15. Income is dummied out into $\$ 40,000$ increments to facilitate identifying the differential effect of various income ranges on political participation.

16. A $\chi^{2}$ test was performed to examine the relationship between race and whether or not respondents were asked to register, the number of times they were contacted, whether they were contacted by a partisan institution, and whether they were contacted by a nonpartisan institution. The relationship between race and each of these variables was significant to the highest level, $p<.001$. A closer examination demonstrates that the majority of this relationship is based on the significantly lower rates of contacts for Latinos and Asian Americans as compared to Blacks and Whites.

17. These regressions are available upon request.

18. The nonpartisan outreach coefficient is not significant in predicting whether Asian American respondents will donate money.

\section{REFERENCES}

Abrajano, Marisa, and Costas Panagopoulos. 2011. "Does Language Matter? The Impact of Spanish versus English-Language GOTV Efforts on Latino Turnout.” American Politics Research 38 (4): 643-63.

Barker, Lucious, and Jesse J. McCorry. 1976. Black Americans and the Political System. Cambridge: Winthrop.

Barreto, Matt A. 2018. "The Cycle of Undermobilization of Minority Voters." Journal of Race, Ethnicity and Politics 3 (1): 185-8.

Barreto, Matt, and Stephen Nuño. 2011. "The Effectiveness of Co-Ethnic Contact on Latino Political Recruitment. Political Research Quarterly 64: 448-59.

Barreto, Matt, Lorrie Frasure-Yokley, Ange-Marie Hancock, Sylvia Manzano, Karthick Ramakrishnan, Ricardo Ramirez, Gabe Sanchez and Janelle Wong. 2008. Collaborative Multi-racial Post-election Survey (CMPS), 2008. ICPSR35163-vl. Ann Arbor, MI: Inter-university Consortium for Political and Social Research [distributor], 2014-08-21. http://doi.org/10.3886/ICPSR35163.v1.

Beltran, Cristina. 2010. The Trouble with Unity: Latino Politics and the Creation of Identity. New York: Oxford University Press.

Bonilla-Silva, Eduardo. 2014. Racism Without Racists: Color-Blind Racism and the Persistence of Racial Inequality in America, 4th ed. Lanham: Rowman \& Littlefield.

Bowler, Sean, Stephen Nicholson, and Gary Segura. 2006. "Earthquakes and Aftershocks: Race, Direct Democracy, and Partisan Change.” American Journal of Political Science 50 (1): 146-59.

Caldeira, Clausen and Samuel C. Patterson. 1990. "Partisan Mobilization and Electoral Participation." Electoral Studies 9 (3): 191-204.

Campbell, Angus, Phillip Converse, Warren Miller and Donald Stokes. 1960. The American Voter. New York: Wiley.

Christens, Brian D., and Paul W. Speer. 2011. "Contextual Influences on Participation in Community Organizing: A Multilevel Longitudinal Study." American Journal of Community Psychology 47: 253-63. 
Cho, Wendy K. Tam, James G. Gimpel and Joshua J. Dyck. 2006. "Residential Concentration, Political Socialization, and Voter Turnout." The Journal of Politics 68 (1): 156-67.

Dawson, Michael. 1994. Behind the Mule: Race and Class in African-American Politics. Princeton: Princeton University Press.

De la Garza, Rodolfo, Marisa Abrajano, and Jeronima Cortina. 2008. "Get me to the Polls on Time: Co-Ethnic Mobilization and Latino Turnout." In Junn and Haynie (eds). New Race Politics: Understanding Minority and Immigrant Politics. Cambridge: Cambridge University Press.

Erie, Steven P. 1988. Rainbow's End: Irish-Americans and the Dilemmas of Urban Machine Politics, 1840-1985. Berkeley: University of California Press.

Ernst, R. 2010. The Price of Progressive Politics: The Welfare Rights Movement in an era of Colorblind Racism. New York: NYU Press.

File, Thom. 2013. The Diversifying Electorate-Voting Rates by Race and Hispanic Origin in 2012 (and Other Recent Elections). Population Characteristics. Current Population Survey. https://www.census.gov/prod/2013pubs/p20-568.pdf. Accessed 20 September 2016.

Finkel, S.E. 1985. "Reciprocal Effects of Participation and Political Efficacy: A Panel Analysis." American Journal of Political Science 29 (4): 891-913.

Frey, William. 2018. "The US Will Become 'Minority White' in 2045, Census Projects: Youthful Minorities Are the Engine of Future Growth." Brookings. https://www. brookings.edu/blog/the-avenue/2018/03/14/the-us-will-become-minority-white-in-2045census-projects/.

Frymer, P. 2008. Black and Blue: African Americans, the Labor Movement, and the Decline of the Democratic Party (Princeton Studies in American Politics). Princeton: Princeton University Press.

Frymer, Paul 2011. "Debating the Causes of Party Polarization in America." California Law Review 99 (2): 335-49.

Garcia-Bedolla, Lisa, and Melissa Michelson. 2012. Mobilizing Inclusion: Transforming the Electorate Through Get-Out-the-Vote Campaigns. New Haven: Yale University Press.

Garcia-Bedolla, Lisa, and Melissa Michelson. 2014. "Mobilization by Different Means: Nativity and GOTV in the United States." International Migration Review 48 (3): $710-27$.

Gay, C. 2002. Spirals of Trust? The Effect of Descriptive Representation on the Relationship Between Citizens and Their Government. American Journal of Political Science 46 (4): 717-32.

Green, D.P. and R. Shachar 2000. "Habit Formation and Political Behavior: Evidence of Consuetude in Voter Turnout." British Journal of Political Science 30 (4): 561-73.

Han, H. 2009. Moved to Action: Motivation, Participation, and Inequality in American Politics. Stanford, CA: Stanford University Press.

Han, H. 2014. How Organizations Develop Activists: Civic Associations and Leadership in the 21st Century. New York: Oxford University Press.

Han, Hahrie. 2016. "The Organizational Roots of Political Activism: Field Experiments on Creating a Relational Context." American Political Science Review 110 (2): 296-307.

Haney-Lopez, Ian F. 2003. Racism on Trial: The Chicano Fight for Justice Cambridge: Harvard University Press.

Hochschild, Jennifer. 2009. Bringing Outsiders In: Transatlantic Perspectives on Immigrant Political Incorporation. Ithaca, NY: Cornell University Press.

Holbrook, Allyson and Jon Krosnick. 2010a. "Social Desirability Bias in Voter Turnout Reports.” Public Opinion Quarterly 74 (1): 37-67. 
Holbrook, A.L. and J.A. Krosnick, 2010b. "Measuring Voter Turnout by Using the Randomized Response Technique: Evidence Calling Into Question the Method's Validity." Public Opinion Quarterly 74 (2): 328-43.

Jacobson, Robin Dale. 2008. The New Nativism: Proposition 187 and the Debate Over Immigration. Minneapolis: Univ. of Minnesota Press.

Junn, Jane and Natalie Masuoka. 2013. The Politics of Belonging: Race, Public Opinion, and Immigration. Chicago: University of Chicago Press.

Juravich, Nick. 2017. “We the Tenants': Resident Organizing in New York City's Public Housing, 1964-1978." Journal of Urban History 43 (3): 400-20.

Klofstad, Casey A. and Benjamin G. Bishin. 2013. "Do Social Ties Encourage Immigrant Voters to Participate in Other Campaign Activities?" Social Science Quarterly 95 (2): 295-310.

Krogstad, Jens Manuel, Mark Hugo Lopez, Gustavo Lopéz, Jeffrey S. Passel and Eileen Patten. 2016. Looking Forward to 2016: The Changing Latino Electorate. Washington, DC: Pew Research Center-Hispanic Trends.

Leighley, J.E. 2001. Strength in Numbers?: The Political Mobilization of Racial and Ethnic Minorities. Princeton: Princeton University Press.

Leighley, Jan E. and Arnold Vedlitz. 1999. "Race, Ethnicity, and Political Participation: Competing Models and Contrasting Explanations." The Journal of Politics 61 (4): 1092.

Lerman, Amy and Vesla Weaver. 2014. Arresting Citizenship: The Democratic Consequences of American Crime Control. Chicago: University of Chicago Press.

LeRoux, Kelly and Krawczyk, Kelly. 2014. "Can Nonprofit Organizations Increase Voter Turnout? Findings From an Agency-Based Voter Mobilization Experiment." Nonprofit and Voluntary Sector Quarterly 43 (2): 272-92.

Lien, Pei-te, Christian Collet, Janelle Wong and S. Karthick Ramakrishnan. 2001. "Asian Pacific-American Public Opinion and Political Participation." PS: Political Science and Politics 34 (3): 625-30.

Lien, Pei-te, M. Margaret Conway and Janelle Wong. 2004 The Politics of Asian Americans: Diversity and Community. New York: Routledge.

McDaniel, Eric L. 2008. Politics in the Pews. Ann Arbor: University of Michigan Press.

Michelson, M. 2003a. "The Corrosive Effect of Acculturation: How Mexican Americans Lose Political Trust." Social Science Quarterly 84 (4): 918-33.

Michelson, M. 2003b. "Getting Out the Latino Vote: How Door-to-Door Canvassing Influences Voter Turnout in Rural Central California." Political Behavior 25 (3): 247-63.

Mora, Cristina. 2014. Making Hispanics: How Activists, Bureaucrats, and Media Constructed a New American. Chicago: University of Chicago Press.

Nelson, William and Philip Meranto. 1977. Electing Black Mayors: Political Action in the Black Community. Columbus: Ohio State University Press.

Nuño, Stephen A. 2007. "Latino Mobilization and Vote Choice in the 2000 Presidential Election." American Politics Research 35 (2): 273-93.

Owens, Michael Leo. 2014. "Ex-Felons' Organization-Based Political Work for Carceral Reforms." The Annals of the American Academy of Political and Social Science 651: 256-64.

Pantoja, A., Ramirez, R. and Segura, G. 2001. "Citizens by Choice, Voters by Necessity: Patterns in Political Mobilization by Naturalized Latinos." Political Research Quarterly 54(4): 729-50.

Pantoja, Adrian D. and Gary M. Segura. 2003a. "Does Ethnicity Matter? Descriptive Representation in Legislatures and Political Alienation Among Latinos." Social Science Quarterly 84(2):441-60. 
Pantoja, Adrian D. and Gary M. Segura. 2003b. "Fear and Loathing in California: Contextual Threat and Political Sophistication among Latino Voters." Political Behavior 25 (3): 265-86.

Parker, Christopher S. 2009. Fighting for Democracy: Black Veterans and the Struggle Against White Supremacy in the Postwar South. Princeton: Princeton University Press.

Pedraza, Francisco. 2014. "The Two-Way Street of Acculturation, Discrimination, and Latino Immigration Restrictionism.” Political Research Quarterly 67 (4): 889-904.

Persson, Mikael and Maria Solevid. 2013. "Measuring Political Participation-Testing Social Desirability Bias in a Web-Survey Experiment." International Journal of Public Opinion Research 26 (1): 98-112.

Peters, Jeremy W. 2016. "Donald Trump is Seen as Helping Push Asian Americans into Democratic Arms." The New York Times, October 1.

Philpot, Tasha, Daron Shaw and Ernest McGowen. 2009. "Winning the Race: Black Voter Turnout in the 2008 Presidential Election.” Public Opinion Quarterly 73(5): 995.

Putnam, Robert D. and David E. Campbell. 2010. American Grace: How Religion Divides and Unites Us. New York: Simon \& Schuster.

Ramakrishnan, S. 2005. Democracy in Immigrant America: Changing Demographics and Political Participation. Stanford: Stanford University Press.

Ramirez, Ricardo. 2005. "Giving Voice to Latino Voters: A Field Experiment on the Effectiveness of a National Nonpartisan Mobilization Effort." The Annals of the American Academy of Political and Social Science 601 (66): 66-84.

Ramirez, Ricardo. 2007. "Segmented Mobilization: Latino Nonpatisan Get-Out-the-Vote Efforts in the 2000 General Election." American Politics Research 35(2): 155-75.

Ramirez, Ricardo. 2013. Mobilizing Opportunities: The Evolving Latino Electorate and the Future of American Politics. Charlottesville: University of Virginia Press.

Ramirez, Ricardo, Romelia Solano and Bryan Wilcox-Archuleta. 2018. "Selective Recruitment or Voter Neglect? Race, Place, and Voter Mobilization in 2016." Journal of Race Ethnicity, and Politics 3 (1): 156-84.

Reese, E. and Newcombe, G., 2003. Income Rights, Mothers' Rights, or Workers' Rights? Collective Action Frames, Organizational Ideologies, and the American Welfare Rights Movement. Social Problems 50 (2): 294-318.

Rosenstone, S., and John Mark Hansen. 1993. Mobilization, Participation, and Democracy in America, New York: Macmillan Publishing Company.

Schildkraut, Deborah J. 2005. "The Rise and Fall of Political Engagement among Latinos: The Role of Identity and Perceptions of Discrimination." Political Behavior 27 (3): 285-312.

Shingles, R. 1981. "Black Consciousness and Political Participation: The Missing Link." The American Political Science Review 75 (1): 76-91.

Stevens, Daniel and Benjamin G. Bishin. 2011. "Getting out the Vote: Minority Mobilization in a Presidential Election." Political Behavior 33 (1): 113-38.

Stockemer, D. 2014. What Drives Unconventional Political Participation? A two Level Study. The Social Science Journal 51 (2): 201-11.

Terriquez, Veronica. 2011. "Schools for Democracy: Labor Union Participation and Latino Immigrant Parents' School-Based Civic Engagement.” American Sociological Review 76 (4): 581-601.

"The Rise of Asian Americans." 2013. Pew Research Center. http://www.pewsocialtrends. org/files/2013/04/Asian-Americans-new-full-report-04-2013.pdf

Uhlaner, Carole J., Bruce E. Cain and D. Roderick Kiewiet 1989. "Political Participation of Ethnic Minorities in the 1980s." Political Behavior 11 (3): 195-231.

Varsanyi, Monica. 2005. "The Paradox of Contemporary Immigrant Political Mobilization: Organized Labor, Undocumented Migrants, and Electoral Participation in Los Angeles" Antipode 27 (4): 775-95. 
Verba, Sidney, Kay Schlozman and Henry Brady. 1995. Voice and Equality: Civic Volunteerism in American Politics. Cambridge: Harvard University Press.

Walton, Hanes. 1994. Black Politics and Black Political Behavior: A Linkage Analysis. Westport: Praeger.

Walton, Hanes, and Marion Orr. 2005. African American Independent Politics on the Left. Souls 7 (2): 19-33.

Wielhouwer, Peter and Brad Lockerbie. 1994. "Party Contacting and Political Participation, 1952-90.” American Political Science Review 38 (1): 211-29.

Wilson, Thomas C. 2001. "Americans' Views on Immigration Policy: Testing the Role of Hreatened Group Interests." Sociological Perspectives 44 (4): 485-501.

Wolfinger, R. and Steven J. Rosenstone. 1980. Who Votes? New Haven: Yale University Press.

Wong, Janelle. 2000. “The Effects of Age and Political Exposure on the Development of Party Identification among Asian American and Latino Immigrants in the United States." Political Behavior 22 (4): 341-71.

Wong, Janelle. 2005. "Mobilizing Asian American Voters: A Field Experiment." The Annals of the American Academy 601 (1): 102-14.

Wong, Janelle. 2006. Democracy's Promise: Immigrants and American Civic Institutions. Ann Arbor: University of Michigan Press.

Wong, Janelle S. 2015. "The Role of Born-Again Identity on the Political Attitudes of Whites, Blacks, Latinos, and Asian Americans.” Politics and Religion 8 (4): 641-78.

Wong, Janelle S., Pei-Te Lien and M. Margaret Conway. 2005. "Group-based Resources and Political Participation among Asian Americans." American Politics Research 33 (4): 545-76.

Wong, Janelle, Karthick Ramakrishnan, Taeku Lee and Jane Junn. 2011. Asian American Political Participation: Emerging Constituents and Their Political Identities. New York: Russell Sage.

Zepeda-Millán, C., 2017. Latino Mass Mobilization: Immigration, Racialization, and Activism. Cambridge: Cambridge University Press.

Zukin, Cliff, Scott Keeter, Molly Andolina, Krista Jenkins and Michael X. Delli Carpini. 2006. A New Engagement? Political Participation, Civic Life, and the Changing American Citizen. New York: Oxford University Press. 